\title{
7 \\ Overcoming Poverty Through Sustainable Development
}

Héctor Sejenovich

\section{Introduction}

Latin America is home to alarming poverty rates and the greatest inequality gap in the world (ECLAC, 2010). The concentration of wealth has disadvantaged local populations and their needs, while simultaneously driving the degradation and destruction of natural resources. This process has rendered serious implications for climate change (IPCC, 2007; Sandberg and Sandberg, 2010). While economic constraints are perhaps the most important aspect of poverty, they are only one of many that impede the personal development of the population (Cimadamore and Cattani, 2008; Cimadamore and Sejenovich 2010).

Latin America accounts for only $8 \%$ of the world's population, but it is home to a significant portion of the planet's natural resources. This includes $46 \%$ of rainforests, $23 \%$ of forests and savannahs, $30 \%$ of freshwater (from a stable potable source), $30 \%$ of permanent crops, $23 \%$ of arable land, $17.7 \%$ of grassland and $16 \%$ of cattle-ranching land (Sejenovich and Panario, 1997). At the same time, as a geographical area it has shown significant industrial, infrastructural and financial development. This means that it has the potential to improve its productive activities in order to meet the needs of the population. However, there is a significant degree of social exclusion and poverty due to systematic disparities in income, possession of resources and power. While the rhythm of productive development has kept momentum, so has the destruction of natural resources and unsustainable use of biodiversity. As a result, the high concentration of monocrops has displaced populations, thereby accelerating the intensification of rural and urban poverty alike. Similarly, urban development has not followed environmental principles and has therefore contributed to pollution, habitat degradation 
and adverse effects on the health of the population (Alimonda, 2006). In order to reverse this situation, we must analyse the relationship between the concepts of poverty and sustainable development.

Poverty levels in Latin America depend not only on monetary income but also on the natural, infrastructural and social context in which the poor live and which does not allow them to reverse the situation. That would require much more than just increasing their income level; it would require sociocultural and health measures, new homes, participation in environmental governance and so forth. While the World Bank (2014) predicted less poverty in Latin American in the near future, the reports of the Economic Commission for Latin America (CEPAL, 2008; ECLAC, 2010, 2013) tell a contrasting story. Since the era of neoliberalism there has been a relative decline in poverty, but the region has maintained a high absolute level of poverty. In 2010, according to ECLAC, there were 177 million poor people, 70 million of whom were indigent (people whose income did not cover their subsistence).

We can indeed see that the poverty rate reached $48 \%$ of the total population in 1990 and 44\% in 2002, and only in 2011 did it drop significantly to $27 \%$ (ECLAC, 2013). In the case of active, socially inclusive, redistributive states, asset levels decreased dramatically. Although there are positive aspects to this new situation, it should be noted that overall funding for these actions comes from the overexploitation of nature. Furthermore, they are contingency measures that are not based on stable yields and can therefore be reversed. According to the ECLAC report, the changes in poverty rate from 2002 to 2011 are as follows: Ecuador dropped from $49 \%$ to $32 \%$; Argentina from 35\% to 5.7\% (this is debatable due to the evolution of prices within the country); and Venezuela from $40 \%$ to $32 \%$. These changes were primarily due to subsidized employment that was reduced with the onset of the crisis. This situation is especially serious for children. According to CEPAL (2008), in 2000 it was estimated that approximately 36\% of Latin American children under the age of two years were at high nutritional risk (i.e. their minimum subsistence needs were not being covered). Even in Argentina, which can produce food for a much larger population than it has, the Pan American Health Organization (PAHO, 2010) estimated that in greater Buenos Aires one in five children was malnourished. This situation has improved somewhat in subsequent years, according to ECLAC (2013: 14):

These measurements are encouraging, with all countries reporting a decrease in the percentage of children under 18 who are deprived 
of some basic rights (overall poverty). In the region as a whole (14 countries, comparable over time at national level), overall child poverty fell by over 14 percentage points over the period, from $55.3 \%$ of children in around 2000 to $41.2 \%$ around 2011.

For the abovementioned reasons it is difficult to resolve the structural poverty that plagues Latin America and which is the result of production patterns, which fail to absorb the quantum and dynamics of the economically active population and seem unable to reverse the concentration of production and income. Rather than identify and analysing these facts, though necessary, we should concentrate on analysing the costs of past damage and how to reverse this situation structurally and quickly.

\section{The conflict between poverty and sustainable development}

In Latin America the relationship between poverty, environmental crisis and short-term accumulation in this age of globalization presents a particular complexity. The environmental issue is a fundamental part of the inequality and dependency issue of the development model (MartinezAlier et al., 2010). In search of alternatives, theory can play an important role by showing that we have the resources and capabilities to change the situation. This requires better distribution and organization, which can give us a sustainable and socially just development (Salvia, 2011).

Development indicators such as gross domestic product (GDP) only highlight the productive face of development and ignore the degradation and waste that it causes. The social destination of production is geared towards those who can manifest themselves in the market, thereby satisfying needs while also generating poverty and misery for those who do not meet the minimum necessary income. The lifetime of products is reduced to avoid market saturation, leading to a significant generation of waste and pollution. Therefore, development indicators must be reworked.

The development of equity accounts indicates a fruitful path (Sejenovich and Gallo Mendoza, 1997). As a result of this conceptualization, an integrated and sustainable management of natural resources, habitat conservation, and energy and human capacity finally seems to be possible. It is essential, however, to consider all the negative externalities of state development projects. The production process neither begins with the traditional natural resource (because tasks must be performed in order to regenerate the resource in an integral manner) 
nor ends with the production of goods (the provision of its "return to nature", in terms of waste, must be analysed in order to prevent additional contamination). The eradication of poverty - and development of quality of life - implies a dynamic link between the individual, the community and the environment. The satisfaction of human needs is strongly associated with the continuous and creative participation of social partners and public policy in the transformation of the material, socioenvironmental and cultural conditions of production and of life. Social struggles energize and drive both individual and social development around situations that are changing and where there are projects for the future.

To achieve a reduction in poverty by ensuring equality requires a rethinking and modification of the current relationship between society and nature. This implies, among other things, a change in the technological pattern of production and consumption as well as a more equitable distribution of income (Anguelovski and Martinez Alier, 2014). Although the task seems difficult, there is really no alternative. The random occupation of space, the gigantic and uncontrolled scale of technology, and the destructive forms of short-term and unplanned use of natural assets and the habitat will exceed the limits of the biosphere. The effects of such activity are already manifested in climate change, food crises, structural poverty and social insecurity worldwide.

To the abovementioned income inequality we can add discrimination based on gender, age, language, identity, religion and different capabilities. This gives the dominant sector an excuse to pay lower wages to unskilled workers, thus yielding additional income. Therefore it is crucial that the state implements redistributive policies in order to improve employment rates and quality of life for the overall population. It is important to keep in mind that, depending on the year, $70-80 \%$ of the population possesses no more than $20-40 \%$ of the GDP in Latin America. It is also essential that the government implements a socioenvironmental system for land use, which should control the application of social as well as environmental legislation.

However, the state does not always apply these policies. As a result, the population suffers unmet needs and environmental degradation. The perception of this situation and the desire for change generate social and environmental movements that demand specific or more profound changes. The sciences provide tools for understanding these complex phenomena and for exploring potential alternatives, thus generating theoretical movements. In response to these social and scientific demands, the state typically begins with the implementation of changes 
and the definition of some policies. The relative strength of these actors determines the kind of change that is generated, as well as its future stability. In this way, grassroots environmental governance is created (Cimadamore and Cattani, 2008; García Linera, 2008).

In recent decades, changes in environmental governance in Latin America have stimulated the participation of different social actors who strive to implement environmental policies to improve quality of life and environment. Environmental governance can advance this development by ensuring the greatest participation of different social actors with conflicting interests. This is undoubtedly the axis from which different problems can be resolved (Kooiman 2005). It demands that the social sciences - in both theory and practice - deepen their concepts from multiple interactive perspectives in thematic, temporal and spatial respects. This line of action reinforces a more comprehensive view of the relationship between society and nature, and strengthens the intervention methodologies that allow for its implementation. In this way, social science research can collaborate with social movements and the state (and the actors involved in it) to more clearly visualize contradictions and challenges. Although success is not guaranteed, this is a vehicle that environmental movements should use intensively and that the state should permit and promote. It is an integral part of the democratization of the state.

This spectrum of environmental movement actions commits academic researchers to social sensitivity. It allows for their positive interference in conflicts and enriches natural and social sciences by incorporating research and action in the face of environmental challenges. Especially in Latin America, it is essential to rethink development issues in order to make the concept of sustainability more holistic. To do so, we must overcome the economic and social constraints to accessing products and services. The poor do not reach the minimally required threshold, and as a response they form social movements to demand more jobs and income. If the struggles are truly economic, they are integrated into a situation of greater social and cultural marginalization. At the same time, they attempt to address the overaccumulation of capital and power, taking advantage of a number of disparities among the population. This is the case for gender (where women are remunerated with lower wages than men and demand real equality); ethnicity (by claiming equal treatment); language (allowing for a multinational society); age (developing a policy of inclusion and protection for children and the elderly); difference in religion (where freedom of conscience is claimed); nationality (equal treatment); identity (where several concepts 
that address the history, their relationship with nature, and their relationship with a diversity of worldviews, society and nature are articulated); and different capabilities (respecting apparent limitations and enhancing capabilities).

The same fundamental categories that allow us to analyse the transformation of nature and its relationships will reveal the obstacles that inhibit the sustainable management of natural resources and the improvement of the quality of life of the population. This process demonstrates how the "organic whole" works - production, distribution, exchange and consumption. Instead of meeting the needs of the population, it only increases the income of the wealthiest. This generates negative externalities in both ecological and socioeconomic terms (Sejenovich, 2012).

Therefore, in order to increase the quality of life, we must implement different policies, actions and strategies that allow us to achieve our goal of sustainable development (Redclift, 1987). These objectives must overcome the myths about development that have been generated over several decades in Latin America - they must become countermyths or "fallacies", as demonstrated by Kliksberg (2014).

\section{The role of social rights}

The definition of "poverty" - always normative by nature - is relative. It depends on the epistemic frame in which the minimum conditions and life needs required for their survival, development and reproduction are set. In contrast with the economist perspective of "welfare" which is rooted in neoclassical (welfare economics) and developmentalist (favouring the gross output and income share) approaches - the concept of "quality of life" recognizes poverty not only as an unfair deprivation of basic human necessities but also as directly related to sustainable development.

Sustainable development is highly sensitive to the relationship among environmental dynamics, socioeconomic processes, sociocultural orientations and the sociopolitical actions of those who are subject to these conditions (Stahler-Sholk, Vanden and Kuecker, 2008; UNDP, 2014). In this regard it should be noted that improving the quality of life implies a dynamic link between the individuals and their environment. The satisfaction of human needs is strongly associated with the continuous and creative participation of social partners in transforming reality. This means a process in which the conflict energizes and drives development, both individual and social, around changing situations. 
It is worth noting that - for individuals as well as for the collective needs and satisfactions are perceived from within a frame of representations. Likewise, values are determined by the place occupied in the social structure, at a particular time and in a given society. We must also consider that the struggle for adequate quality of life refers to relationships with objects and with a potentially peremptory and changing nature. Considering that individuals are driven also by subjective perceptions, a range of meanings emerge as the subject is formed from the material as well as the imaginary aspects of the object (Salvia, 2011).

Therefore, rather than material gains (goods) that we obtain from a better quality of life, we should consider the struggle among the involved social sectors and the ways people can develop their capabilities. The latter could be a greater objective - to strive for the comprehensive development of the population. Therefore, the processes of each ecosystem are analysed through three different sets of satisfaction rights necessary to "sustain" the relationship between development, environment and quality of life.

Right to livelihood: This right establishes the need to ensure the items or natural, technological and social processes that allow people to construct a convivial society. This includes a conservative and productive management of one's habitat to maintain overall health.

Right to protection: This is the right to personal development by way of a productive, healthy, satisfying and creative job, striking a dynamic balance with the environment. This includes the right to be protected in a legal and material sense against acts of aggression, abuse or discrimination (economic, ethnic, social, cultural, religious or related to gender). It likewise addresses the full integration of women into society and the triumph over the exclusive assignment of reproductive responsibilities to women, thereby ensuring equal access to productive resources and benefits.

Rights to levels of understanding and to participation: In this case it is the ability to develop and pursue personal, familial and community projects in search of a sustainable better life within an active and growing system of environmental governance as an efficient instrument (Asotorga, Ame and Valpy, 2004). This law also takes into account autonomous political and community participation in matters of public order, without restriction or constraint. This entails overcoming the condition of a mere consumer, adopting the multiple physical and cultural functions of an individual and his or her interpersonal relationships.

By taking into account the interdisciplinary and multiscale methodology of environmental governance, we present short illustrative cases 
of four projects in Argentina and Uruguay which meet the criteria of ecosystem representation and progressive levels of social rights.

\section{Illustrative cases}

To analyse how society transforms nature to improve quality of life, one must employ an interpretative framework that can be accessed through interdisciplinary exercises. In this section we briefly describe four case studies to define the needs/rights that can overcome levels of poverty based on different analytical levels and territorial characteristics (rural, urban and extractive).

The transformation of society - the systemic relationship among production, distribution and consumption - is always the result of the rationality imposed by a historical social formation. The latter imprints a particular modality on the process of transformation and then determines the social destination of production (for whom it is produced), the technological form (how it is produced), a certain level of production (where it occurs) and a demand for natural resources and a particular habitat (with what natural and social resources it is produced). It gives priority to cases that obtain short-term gain and generates concrete products that meet certain criteria, negative externalities that are generally not considered (Sejenovich, 2000). All nature is socially mediated and social relations operate in a natural structure with which they constantly interact, in such a way that all sectors form part of the manifestation of the society-nature relationship.

An example of the integrated and sustainable use of natural resources is the ecosystem of the basin of the Angostura river, where the village of Tafi del Valle is located. In the mountainous area of northwestern Argentina, in the province of Tucumán, this area is similar to the Peruvian highlands (Valdivia and Gilles, 2006; Gonzalez et al., 2010). The socioeconomic process comprises an integrated management of a protected territory to overcome the existing grazing area. Environmental production policies attempted to replace the introduced fauna with a native species, such as the camelid.

As for food and nutrition security, it is evident that subsistence rights are being regularly met. Stable employment, however, has not been guaranteed. However, the use of the landscape for activities of responsible tourism is also an important potential source of employment. Regarding the pressure (both tangible and intangible) on natural resources, yearly and seasonal population increase give rise to rural districts. In terms of rights of protection and participation, the guarantees 
maintained for the original population should be kept in mind. This includes access to means of communication - and participation in general community initiatives - for the original population and the native communities. Through the integrated and sustainable management of resources in a highly fragile area $(48,000 \mathrm{Ha}), 130$ people have come to permanently occupy the land. This therefore guarantees the eradication of poverty, considering the cultural and communal aspects that already exist in the area.

A second example explores the strategy for sustainable development pursued by Gualeguaychu, and the impact of pulp mills in the community of Fray Bentos, Uruguay. The city of Gualeguaychu is developing a number of important industrial activities and implements agricultural and service activities - especially those involving tourism - in its ecosystems. The development of tourism and agriculture cemented the foundation for a more comprehensive and prolonged growth. This same growth has been threatened by the installation of two cellulose complexes on the Uruguayan shore, which have had negative impacts since 2003. In response, the population protested through legal and not-solegal means, such as the occupation of highways and border bridges. Multiple studies have been conducted to demonstrate and quantify the environmental damage and lost profits that these projects would generate. They are not limited to ecosystems, infrastructure and urban areas; they also have direct effects on the population itself. The environmental costs are calculated according to the reduction of assets, which is measured on the basis of the harm to nature (Sejenovich et al., 2008).

The calculation of environmental damage and profit loss was not developed in hopes of retribution but as a strategy to put pressure on the international capital that supported the contaminating initiative. The population resorted to all legal means, including claims to international agencies and banks. They even went so far as to get the executive, legislative and judicial branches of the Government of Argentina to appeal before the International Court in The Hague. Although they were not entirely successful, they did prevent a company from being established and were responsible for the diffusion of the methodology of the Environmental Citizens' Organization Assemblies throughout the entire Southern Cone. They were sprouts of the environmental governance movement, where all sectors were expressed. This project is an initiative in the country with the highest incidence of identity crisis among the native population. In the struggle against the impacts of pulp mills in Fray Bentos, the population has essentially been fighting for the right to maintain a healthy environment and a stable landscape with little 
intervention since the time of their ancestors, who wanted to bequeath them the land.

Given the environmental damage, it was essential to develop activities related to the environment in order to value knowledge about local products. Environmental damage and lost profits would exceed the allowable amount of the investment. In each of the ecozones, the potential for integrated and sustainable management can be analysed against the potential loss of biodiversity, costs (of managing natural resources) and benefits (considering the integral and sustainable use of biodiversity), and the lost profits that are its result. If calculated as negative externalities of the project, the total of the land value damages (US\$172,037,600), the value of homes (US\$320,000,000) and the damage to health (US\$68,726,000) should reduce the companies' profits to the extent that the project could be economically unviable. At the very least, it should offer incentives for a more sustainable implementation. Despite the pressure exerted at every level, the huge power of international capital managed to ignore the externalities (and not pay for them), and instead to install the pulp mill with a very high rate of return.

Another instance of the nature-society contradiction can be found in the soyabean industry in Argentina. Concentrated in the Pampas region, the nucleus of the most fertile land in the country, it is another example of an oligopolistic accumulation of natural resources. The soyabean monoculture brings with it high productivity and a series of direct and indirect negative impacts. These include degradation and waste of natural resources, habitat pollution, and impacts on the population in economic, social, cultural and especially health terms. In fact, an increased incidence of cancer has been found and is likely due to the effect of the agrochemical glyphosate (Carrasco, 2012; Dougnac Martínez, 2013; IARC 2015). This danger was recently echoed by the World Health Organisation (WHO).

The monoculture of soyabean (Slutzky, 2011) - currently the primary export crop of Argentina - has replaced cattle grazing and other crops, such as cotton, lentils, milk, meat and rice. As a result, there have been shortages and increases in the Argentinean food basket. This expansion is made possible by the hegemony of financial capital that rents fields and machinery for monoproduction, thus displacing small and medium farmers. This ultimately results in poverty and displacement to urban areas, and furthermore to the expansion of the agricultural frontier into land that is not meant for agricultural use (Bustamante and Maldonado, 2008). Given that soyabean 
production has displaced traditional foods, cultivation directly affects the Argentinean food structure and the right to subsistence. Much has been written about the alternatives to soyabean production, oriented towards comprehensive and sustainable resource management and poverty alleviation. For example, agroecology can be a highly productive process on a per-hectare basis. This maintains diversity, ensures the full use of land and provides an answer to rural poverty. This strategy will enable widespread environmental governance in rural ecosystems precisely because it involves the grouping together of occupations to be able to research, monitor and manage all of the plants. In turn, this generates significant revenue for the producer group. It also entails potential advantages in terms of the nutrition and diversity of food supply. However, a change of this nature would involve major changes in the line of interest within their respective elites.

The Matanza-Riachuelo Basin (Cuenca Matanza-Riachuelo (CMR)) project serves as our final example. The CMR spans part of the city of Buenos Aires and 15 surrounding municipalities, encompassing an area of $2,338 \mathrm{~km}^{2}$ (the length of the main channel is $70 \mathrm{~km}$ ). It is estimated that 5.3 million permanent residents and at least 3 million more commuters use CMR for transit. It is considered to be the centre of Argentine industrial development, but 23,523 companies which are active in the region have been registered as potential sources of pollution.

Ever since the colonial period, the contamination of the basin has generated significant actions, such as moving salt production to improve the water quality. It then suffered a second contamination from new industries, which affected the health of the population (ACUMAR, 2007). As a result, the state was sued by the direct victims in a case involving the Supreme Court of Argentina (2006). Known as the "Mendoza Cause", it was based on the implementation of court orders to restore the watershed and to improve the quality of life of the population. To meet this objective an interinstitutional body called the Matanza-Riachuelo Basin Authority (ACUMAR) was established. According to official data (2014), 459 industries have been converted; 289 have been closed; 1,364 have initiated a restructuring process; and 1,436 have presented plans to expand.

The right to livelihood is being met through decontamination to improve the health of the population. This includes the installation of sewage and clean-water pipelines, and the building of new homes and villas to eliminate slums and precarious housing. As of now, 17,771 people have benefited and $85 \%$ of the area's population will have clean water, better satisfying their needs and improving their quality of life. 
A greater participation process has also been observed in the advisory body of the ACUMAR, which includes universities and NGOs. It is safe to say that environmental governance is becoming more effective by improving environmental conditions, poverty and subsistence issues, but they are changes that need to be accelerated (AySA, 2009).

The construction of major infrastructural projects allows us to visualize the fundamental aspects of watershed management. With the decontamination of the CMR and the solution of the problems of housing and services, there is no doubt that one of the main obstacles associated with poverty will be overcome.

\section{Key trends and the struggle for sustainable development}

From the illustrative cases discussed here, the experiences and expertise of consultants, and other global studies, several general considerations about the relationship between environmental governance and poverty in Latin America have arisen.

Powerful economic groups continue to adopt highly concentrated exploitation and environmental degradation policies that violate not only socioeconomic resources of local livelihoods but also the sociopolitical capacity to design, plan and implement sustainable socioenvironmental development. Environmental policies are often not heeded. At different levels of government the state has failed to define the full potential and limitations that should regulate monocultures, especially that of soyabean cultivation. In fact, tax returns generated by this activity are privileged and no existing laws apply to regulate them. An example of successful environmental regulation is the case of the Forest Act and the Environment Act in Argentina, where environmental planning is legislated. Agricultural confederations such as the Rural Society, the Agrarian Federation, Coninagro, CRA, various trade associations and the Chamber of Commerce have succeeded in imposing their interests on developing soyabean activity. This often overshadows the claims and legal actions of other social actors, including those of the state.

The soyabean expansion case in Argentina can be expanded to the whole region as the ecosystems that have already been transformed (the humid pampas grasslands, subtropical jungle, scrubland, gallery forest) occupy a critical percentage of arable land in Latin America. The organization of the state apparatus is not neutral. The institutional legal structure in Latin America is essentially developmentalist and will therefore favour the amount and dynamics of production, regardless of its impact, if environmental policies are not enforced. Although the 
impacts of economies of scale have generated cost reductions, they are not translated into prices. Rather than improving the welfare of the general population, the oligopolistic market conditions have allowed large companies to increase profits. As a result, the "progressive spill" did not occur. In general, the rate of accumulation appears to impose oligopolistic structural rules of impoverishment, inequality and social exclusion. This is in addition to the processes of ecological impoverishment that result from ecosystem homogenization and environmental degradation.

These negative outcomes drive disputes in all illustrative cases. In Matanza-Riachuelo Basin, the creation of an intergovernmental body ACUMAR, which has as its first priority to preserve and restore the Matanza-Riachuelo watershed with a range of public and non-public organisms - shows positive developments. In urban ecosystems the situation is not very different, but there are sociopolitical conditions that make the control, regulation and guidance towards socioenvironmentally sustainable projects more feasible.

However, overall urbanization in Latin America exceeds the guidelines of environmental planning, and this is reflected in almost all countries. The operation of watersheds and respect for their characteristics, under the onslaught of settlement infrastructure, remains a deficit that is frequently raised by environmental movements. One of the most serious problems is the political-economic action carried out by national governments in such projects - along with public action to develop megainfrastructural projects - to resolve problems that have been generated by the improper management of watersheds and ecosystems.

The developmental-productivist paradigm remains hegemonic when it comes to great solutions that affect most of the socioeconomic and sociopolitical regulatory institutions of social reproduction at local, regional and national levels. Many of the presidents' speeches at the Community of Latin American and Caribbean States (CELAC) Summit, in February of 2013 in Santiago de Chile, showed excessive optimism in regard to development actions without exploring certain limits that they really must consider. In any case, they should outline the progress that has been made in mobilizing public awareness and institutional improvements. This is the result of forces within and outside the governments, which fight for a solidary management of nature and among social sectors. To advance, it is important to overcome the temptation of criminalizing protest and for movements to deepen their creativity in action. If these aspects are satisfied, a better quality of life for disadvantaged sectors is possible. 


\section{Conclusion}

The study of different socioeconomic environmental scenarios, under a rights-focused approach, provides purposeful lessons for envisioning the relationship between environmental governance and poverty in Latin America. The organizational forms of the state and its operations should be reoriented to better achieve sustainable development (Kliksberg, 2014).

We observe fundamental contradictions between society and nature. The most general is between economic cycles (short term) and ecological cycles (longer term), presenting incompatibility between temporal horizons. Now is the time to respect the timeframes of regenerative mechanisms. Other contradictions arise from the heterogeneity of ecosystems versus the trend to homogenize exploitation for maximum profit through economies of scale. Following a short-term economic objective, only natural resources with competitive global (and sometimes national) advantage are being used; a comprehensive and appropriate use of resources could prevent the existing diversity from being wasted. This practice is widespread in Latin America, where the generation of short-term income generates ecological, social and cultural impoverishment in the long term.

Furthermore, the administrative structures of the state are predominantly defined by a sectorial vision: production and short-term efficiency are privileged, the importance of interaction is minimized, and there is generally little room granted to the participation and articulation of science, technology and the quality of life of the population. Integrated and sustainable management of nature in environmental governance eventually overcomes the apparent contradiction between protecting the environment and stimulating production.

It is clear that, taking comprehensive production into account, there is a vast increase in production, income, employment, tax base and financial jurisdiction. At the same time, the environment is taken into account in an active and integrated manner, thus preventing the loss of biodiversity.

The ability to generate these productive strategies requires, without a doubt, a training programme to understand the techniques of integrated resource management. Actually, all countries with complex ecosystems and specially those whose forested areas are predominant - apply this principle. We must keep in mind that Latin America possesses nearly half of the world's tropical forests. It increasingly requires new planning processes that incorporate the population from the outset, along with 
the development of scientific interdisciplinary analysis. More and better participation, and a substantial improvement in training, are a priority for all governments. This aspect was particularly stressed at Rio+20.

Environmental governance of the land, patrimonial accounts, environmental assessment of investment projects, evaluation of environmental impacts, strategic environmental assessments and so forth are emerging as important alternatives. According to ECLAC (2010:140), "Territorial heterogeneity in Latin America calls for selective and targeted strategies. Local development, understood as a bottom-up process, mobilizes endogenous potential to build territories that are better able to create and drive their own capacities." The objectives of the National Environmental Governance Project in each country must reverse the process of poverty generation and, in turn, give more momentum to tasks already under way to directly improve the situation. Habitat improvement and policies to combat environmental degradation are systematically integrated with the possibility for a better life. In addition, the use of unusual environmental policies in Latin American countries - such as tax policies, credit, tariff or integration - all signify that there is a long way to go.

While these ideas are technologically plausible, and are also key for the sustainability of the planet, it is worth reiterating critical doubts that arise from both historical experience and theory. They question the ability of the current model of accumulation and the political regime of domination to advance socioeconomic and environmental sustainable development, without significant changes. The historical scenario seems to prolong an insurmountable contradiction between the interests to produce, distribute and consume, and the need to ensure social and environmental human life. Therefore, a greater organization and activity of environmental social movements emerges as a possible alternative.

An organizational form for sustainable development within environmental governance involves a holistic view, a direct relationship between research and action. It is a combination of the short, medium and long term, and of a generally high level of participation among civil society and social movements. It proposes implementing the necessary changes and taking actions that can lead to more successful forms of environmental governance and a better quality of life. Economic understanding must be open to all necessary actors, which requires reformulating the conditions for recovery and reproduction of capital with ecological, economic, social, technological and political implications. Only then do the desired reduction of poverty and reconciliation with nature truly begin. 


\section{References}

ACUMAR (2007) "Plan Integral Cuenca Matanza-Riachuelo (PISA)", in http:// www.acumar.gov.ar/pdf/PLAN_INTEGRAL_DE_SANEAMIENTO_AMBIENTAL_ DE_LA_CUENCA_MATANZA_RIACHUELO_MARZO_2010.pdf, date accessed 10 January 2015.

Alimonda, H. (ed.) (2006) Los Tormentos de la Materia: Aportes para una Ecología Política Latinoamericana (Buenos Aires: CLACSO).

Anguelovski, I. and Martinez Alier, J. (2014) "The Environmentalism of the Poor: Territory and Place in Disconnected Global Struggles", Ecological Economics 102: 167-1.

Asotorga, P., Ame, R. and Valpy, F. (2004) The Standard of Living in Latin America during the Twentieth Century, University of Oxford Discussion Papers in Economic and Social History 54.

AySA (2009) Estudio Socioeconómico y Ambiental en la Cuenca Matanza Riachuelo. Vol. I, II, III y IV (Buenos Aires: Publicaciones AySA).

Bustamante, M. and Maldonado, G. (2008) "Actores Sociales en el Agro Pampeano Argentino Hoy. Algunos Aportes para su Tipificación", Cuadernos Geográficos 44 (1): 171-191.

Carrasco, A. (2012) Los Efectos Teratogénicos y Genotóxicos del Glifosato. Jefe de Laboratorio de Embriología Molecular de la Facultad de Medicina de Buenos Aires (Argentina: CONICET).

CEPAL (2008) La Transformación Productiva 20 Años Después. Viejos Problemas, Nuevas Oportunidades (Santiago de Chile: CEPAL/Naciones Unidas).

Cimadamore, A. and Cattani, A.D. (eds) (2008) Producción de Pobreza y Desigualdad en América Latina (Bogotá: Siglo del Hombre Editores).

Cimadamore, A. and Sejenovich, H. (2010) "Cambio Climático y Pobreza", in Voces en el Fénix 1(2) (Buenos Aires: UBA/Plan Fénix).

Corte Suprema de Justicia Argentina (2006) "Mendoza, Beatriz Silvia y Otros c/ Estado Nacional y Otros s/ Daños y Perjuicios (Daños Derivados de la Contaminación Ambiental del Río Matanza - Riachuelo)", Buenos Aires. M 1569. XL. Originario.

Dougnac Martínez, G. (ed.) (2013) De Especie Exótica a Monocultivo. Estudios sobre la Expansión de la Soja en Argentina (Buenos Aires: Imago Mundi).

ECLAC (2010) Time for Equality: Closing Gaps, Opening Trails (Santiago de Chile: ECLAC/United Nations).

ECLAC (2013) Social Panorama of Latin America (Santiago de Chile: ECLAC/United Nations).

García Linera, Á. (2008) La Potencia Plebeya. Acción Colectiva e Identidades Indígenas, Obreras y Populares en Bolivia (Buenos Aires: CLACSO/Prometeo).

González, J., Sejenovich, H. et al. (2010) El Uso Integral y Sustentable de los Recursos Naturales a partir de Estudios de Proyectos Productivos Aplicados a la Zona de Tafí del Valle, Provincia de Tucumán, Argentina (Ministerio de Recursos Hídricos y Medio Ambiente de la Provincia de Tucumán/DINAPREI) in http://www.socioambiente.com.ar/index1.htm, date accessed 13 December 2014.

Intergovernmental Panel on Climate Change (2007) Climate Change: Impacts, Adaptation and Vulnerability: Working Group II Contribution to the Fourth Assessment. Report of the IPCC (Cambridge: Cambridge University Press). 
International Agency for Research on Cancer (IARC) (2015) (Guyton, Kathryn Z. et al., "Carcinogenicity of tetrachlorvinphos, parathion, malathion, diazinon, and glyphosate", The Lancet Oncology). 16(5): 490-491

Kliksberg, B. (2014) Otra Economía es Posible. Desde el Consenso de Washington a la Visión de una Nueva Economía (Buenos Aires: La Página).

Kooiman, J. (2005) "Gobernar en Gobernanza", in A. Cerrillo i Martínez (ed.), La Gobernanza Hoy: 10 Textos de Referencia (Madrid: Instituto Nacional de Administración Pública).

Redclift, M. (1987) Sustainable Development. Exploring the Contradictions. (London: Methuen \& Co. Ltd.).

Salvia, A. (2011) "La Medición del Progreso Humano en la Dimensión Social como una Medida de Cumplimiento de Derechos", in M. Rojas (ed.), La Medición del Progreso y del Bienestar. Propuestas para América Latina (México: Foro Consultivo Científico y Tecnológico, A.C.).

Sandberg, A. and Sandberg, T. (2010) "Introduction", in A. Sandberg and T. Sandberg (eds), Climate Change. Who Is Carrying the Burden? (Toronto: Canadian Centre for Policy Alternatives), 11-22.

Sejenovich, H. (2000) "Pobreza y Ambiente: Hacia una Nueva Relación SociedadNaturaleza", Ponencia en el Seminario sobre Desarrollo, Equidad y Cambio Climático, IPCC, La Habana, Cuba.

Sejenovich, H. (2012) "La Calidad de Vida, la Cuestión Ambiental y sus Interrelaciones", in H.I. Farah and L.Vasapollo (eds), Vivir Bien: ¿Paradigma no Capitalista? (Bolivia: CIDES/UMSA).

Sejenovich, H. and Gallo Mendoza, G. (1997) Manual de Cuentas Patrimoniales (México: PNUMA/Fundación Bariloche).

Sejenovich, H. and Panario, D. (1997) Hacia Otro Desarrollo: Una Perspectiva Ambiental (Buenos Aires: Nordan).

Slutzky, D. (2011) Los Cambios Recientes en la Distribución y Tenencia de la Tierra en el País con Especial Referencia a la Región Pampeana: Nuevos y Viejos Actores Sociales (Buenos Aires: Centro de Estudios Urbanos y Regionales, CEUR).

Stahler-Sholk, R., Vanden, H. and Kuecker, D. (eds) (2008) Latin American Social Movements in the Twenty-First Century: Resistance, Power, and Democracy (Lanham MD: Rowman and Lettlefield).

UNDP (2014) "Poverty Reduction Global Programme2014/2017", in http:// www.undp.org/content/undp/en/home/librarypage/poverty-reduction/ EmpoweringLivesBuildingResilience.html, date accessed 13 November 2014.

Valdivia, C. and Gilles, J. (2006) Adapting to Change in the Andes: Practices and Strategies to Address Climate and Market Risks in Vulnerable Agro-Ecosystems (SANREM CUSP Andes Project).

World Bank (2014) "Regional Indicators", in http://povertydata.worldbank.org/ poverty/region/LAC, date accessed 10 December 2014.

Except where otherwise noted, this work is licensed under a Creative Commons Attribution 3.0 Unported License. To view a copy of this license, visit http://creativecommons.org/licenses/by/3.0/ 